\title{
Front Matter: Volume 12074
}

, "Front Matter: Volume 12074," Proc. SPIE 12074, 10th International Symposium on Advanced Optical Manufacturing and Testing Technologies: Novel Optoelectronic Functional Materials and Devices, 1207401 (13 December 2021); doi: 10.1117/12.2623712 and Testing Technologies (AOMATT 2021), 2021, Chengdu, China 


\title{
PROCEEDINGS OF SPIE
}

\section{0th International Symposium on Advanced Optical Manufacturing and Testing Technologies Novel Optoelectronic Functional Materials and Devices}

\author{
Xiaoliang Ma \\ Mingbo Pu \\ Xiong Li \\ Zhuo Xu \\ Costas Fotakis \\ Xiangang Luo \\ Editors
}

14-17 June 2021

Chengdu, China

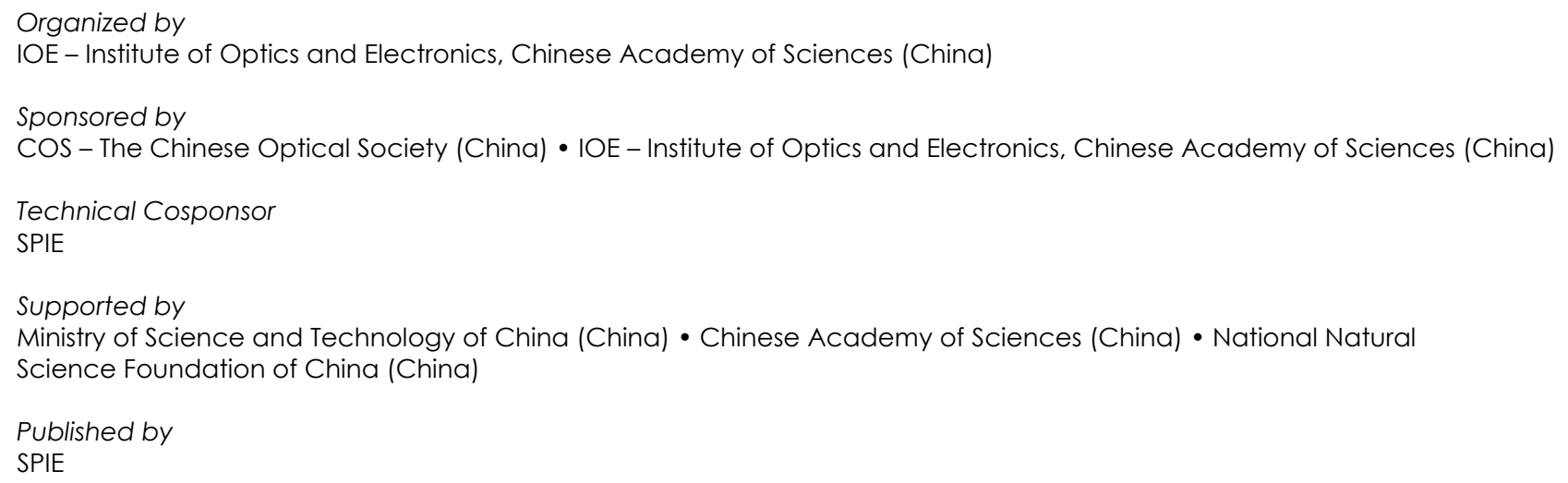

Volume 12074 
The papers in this volume were part of the technical conference cited on the cover and title page. Papers were selected and subject to review by the editors and conference program committee. Some conference presentations may not be available for publication. Additional papers and presentation recordings may be available online in the SPIE Digital Library at SPIEDigitalLibrary.org.

The papers reflect the work and thoughts of the authors and are published herein as submitted. The publisher is not responsible for the validity of the information or for any outcomes resulting from reliance thereon.

Please use the following format to cite material from these proceedings:

Author(s), "Title of Paper," in 10th International Symposium on Advanced Optical Manufacturing and Testing Technologies: Novel Optoelectronic Functional Materials and Devices, edited by Xiaoliang Ma, Mingbo Pu, Xiong Li, Zhuo Xu, Costas Fotakis, Xiangang Luo, Proc. of SPIE 12074, Seven-digit Article CID Number (DD/MM/YYYY); (DOI URL).

ISSN: 0277-786X

ISSN: 1996-756X (electronic)

ISBN: 9781510650237

ISBN: 9781510650244 (electronic)

Published by

SPIE

P.O. Box 10, Bellingham, Washington 98227-0010 USA

Telephone +1 3606763290 (Pacific Time)

SPIE.org

Copyright (C) 2021 Society of Photo-Optical Instrumentation Engineers (SPIE).

Copying of material in this book for internal or personal use, or for the internal or personal use of specific clients, beyond the fair use provisions granted by the U.S. Copyright Law is authorized by SPIE subject to payment of fees. To obtain permission to use and share articles in this volume, visit Copyright Clearance Center at copyright.com. Other copying for republication, resale, advertising or promotion, or any form of systematic or multiple reproduction of any material in this book is prohibited except with permission in writing from the publisher.

Printed in the United States of America by Curran Associates, Inc., under license from SPIE.

Publication of record for individual papers is online in the SPIE Digital Library.

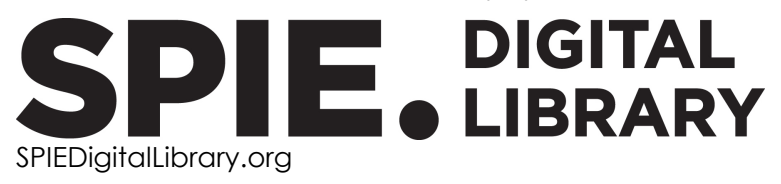

Paper Numbering: A unique citation identifier (CID) number is assigned to each article in the Proceedings of SPIE at the time of publication. Utilization of CIDs allows articles to be fully citable as soon as they are published online, and connects the same identifier to all online and print versions of the publication. SPIE uses a seven-digit CID article numbering system structured as follows:

- The first five digits correspond to the SPIE volume number.

- The last two digits indicate publication order within the volume using a Base 36 numbering system employing both numerals and letters. These two-number sets start with 00, 01, 02, 03, 04, $05,06,07,08,09,0 A, 0 B \ldots$.. OZ, followed by 10-1Z, 20-2Z, etc. The CID Number appears on each page of the manuscript. 


\section{Contents}

\section{NOVEL OPTOELECTRONIC FUNCTIONAL MATERIALS AND DEVICES}

1207402 Modeling of ferrite thin-film structure using FDTD method in optoelectronic devices [12074-18]

1207403 Research based on color uniformity of semiconductor laser [12074-16]

1207404 Field enhancement of tapered focuser with spoof surface plasmon polaritons [12074-26]

1207405 Spectral-domain asymptotics for electromagnetic scattering from a point-source excitation target coated with a uniaxial electric anisotropic medium based on physical optics [12074-40]

1207406 Perovskite/silicon tandem solar cell: surface recombination analysis [12074-24]

$1207407 \quad$ High-performance organic photodetector with optimized thick bulk-heterojunction for nearinfrared sensing [12074-1]

1207408 Crosstalk reduction of silicon waveguide array by high-reflection boundary [12074-17]

1207409 Utilization of perylene diimide derivative doped tin oxide as an electron transport layer for performance enhancement of non-fullerene organic solar cell [12074-5]

12074 OA Research on on-resistance of 4H-SiC photoconductive switch [12074-11]

12074 OB Research on response property of $4 \mathrm{H}-\mathrm{SiC}$ photoconductive switches with the same-side electrode structure [12074-10]

12074 OC Enhanced photoresponse of nanostructured ZnO-based flexible photodetectors [12074-15]

12074 OD Study of a metasurface-based multi-functional polarization converter for large incident angles [12074-12]

12074 OE The material property and electron emission for NEA GaN vacuum electron source [12074-22]

$12074 \mathrm{OF}$ Experiment and analysis of external optical pump modulation for the 0.3BaSrTiO3-0.7NdAIO3 ceramic's characteristics in terahertz range [12074-2]

12074 OG Controllable power transfer in a double-channel magneto-optical photonic crystal waveguide [12074-6]

$12074 \mathrm{OH} \quad$ Suppressed J-V hysteresis in highly efficient inverted perovskite solar cells using smallmolecule non-fullerene acceptor [12074-3] 
12074 Ol Precise adjustment for neutral ternary semitransparent organic photovoltaics by mixing an insulating polymer [12074-14]

12074 J Surface passivation of active layer by introducing sodium alginate for high-performance perovskite photodetectors [12074-4]

12074 OK Conjugated polymer film fabricated by in situ electro-chemical polymerization as effective interface modification material in organic solar cells [12074-13]

12074 OL Efficient FAPbl3 perovskite solar cells using PMACl additives in two-step deposition method [12074-8]

12074 OM Characterization of Kepler structured microlens array scanners for 2D scanning [12074-9]

12074 ON Study on speckle problem in semiconductor laser display [12074-20]

1207400 Surface impedance absorbing boundary condition used for the simulation of frequency selective surfaces [12074-19] 